ON THE BACK COVER:

\title{
AN UNCOLLECTED WHITMAN PROSE MANUSCRIPT
}

This prose fragment, written by Whitman, was found in the front of a first edition copy of November Boughs (1888), now housed in the collection of the Historical Society of Pennsylvania. It is written on the back of a paid furniture bill from J. B. Van Sciver, Philadelphia. Originally published in a limited edition by The Cooper Union, the manuscript is reprinted here with permission. Heavily revised with interpolations and deletions, it reads:

I will want my poems (I had said th mystelf before beginning) to be the poems of Joy. I will want them to be the poems of the Woman entirely as much as of Man. I hadve had the wish to put the true Union of these States in songs without any [illegible word]. Henceforth if they live and are read, I ptdyly it mady hope it must be just as much South as North-just as much along the Pacific as Atlantic-just ds nducth in the valley of the Mississippi, in Kanada, in Texas, the shores of Puget Sound

The manuscript does not appear in Edward Grier's edition of Whitman's Notebooks and Unpublished Prose Manuscripts (1984). 